\title{
Nelsestuen, G. VARRo the Agronomist: Political \\ PHILOSOPHY, SATIRE AND AGRICULTURE IN THE LATE Republic. Columbus: The Ohio University Press, 2015. 316 P.
}

Helton Lourenço ${ }^{1}$

O livro do sul-africano Grant Nelsestuen é produto de sua tese de doutorado sob orientação de Andrew Riggsby e submetida ao departamento de Clássicos da Universidade do Texas em Austin, cujo objetivo é apresentar um estudo sobre o tratado intitulado Rerum Rusticarum escrito por Varrão, eminente militar e erudito romano do último século da República. Na historiografia moderna o tratado de Varrão foi abordado em conjunto com demais tratados de agronomia latina de Catão, Columella e Paládio, e, sobretudo, de um ponto de vista essencialmente econômico. Contudo, diferentemente desta perspectiva, a proposta do autor é analisar o tratado "varroniano" como uma expressão política e ideológica deste intelectual no contexto de formação de um Império mediterrânico.

Deste modo, Grant Nelsestuen destaca que a sua análise perpassa por uma leitura historicizada deste tratado, levando em consideração o contexto histórico romano, notadamente marcado pelas guerras civis e pela expansão da hegemonia romana no mar Mediterrâneo. Neste sentido, ele ressalta que pretende contribuir com os estudos sobre a História Intelectual e Cultural do final da República, e de modo geral com as pesquisas em cursos sobre a Literatura Latina.

Para o autor, o Rerum Rusticarum, se analisado sob o ponto de vista alegóricometafórico pode ser traduzido em uma teoria política do próprio Império Romano. Assim, ele argumenta que a motivação original para esta interpretação depreende de sua percepção de um hiato presente na apresentação formal do texto e o material propriamente técnico exposto na obra de Varrão. Isso posta, o autor questiona que, enquanto os demais tratados sobre a temática agronômica são escritos em "prosa

\footnotetext{
${ }^{1}$ É mestrando em História na Universidade Federal de Ouro Preto sob a orientação do Prof. Dr. Fábio Duarte Joly. É membro do Laboratório de Estudos sobre o Império Romano (LEIR/UFOP). E-mail: carvalhohl@hotmail.com
} 
técnica”, Varrão sistematiza sua versão, sobre este assunto tão caro à sobrevivência e a identidade dos romanos, em forma de três diálogos filosóficos altamente estilizados.

O livro se divide em sete capítulos principais precedidos de uma introdução geral. No primeiro capítulo, “The Form and Genere of Varronian Res Rusticae”, o autor destaca os elementos compositivos e estéticos da obra. Contudo, o autor ressalta que a opção compositiva adotada pelo tratadista não nos permite uma determinação exata e reducionista de sua afiliação. Isso porque, embora a estrutura dialógica esteja presente em todo o Rerum Rusticarum, o tratado é resultado de uma mistura de três gêneros literários que ele qualifica de filosófico-satirico-dialógo técnico. Em outras palavras, o tratado de Varrão combinaria a divulgação de preceitos técnicos sem abrir mão de um debate filosófico permeado por uma atmosfera cômica. Além disso, com características semelhantes aos dos simposym da tradição filosófica da Antiguidade Clássica, o debate revela a falta de consenso sobre o melhor gerenciamento destas atividades, e de forma velada sobre o governo do Império Romano.

O segundo e terceiro capítulos, "Creating the Agronomical field of Res Rusticae" e "Agri Cultura and Italian Farm in Res Rusticae 1" são dedicados à análise do livro primeiro do tratado "varroniano", cuja temática central é o tratamento da agricultura. No segundo, o autor explora a relação do tratado de Varrão com a tradição anterior que aludiu sobre este tema em grego, latino e púnico. Ademais, o autor procura demonstrar que a disputa no interior do dialogo, que divide os participantes sobre o melhor método de cultivo, evidencia uma crescente competição e pedantismo intelectual no seio da aristocracia do final da República.

Assim, no terceiro capítulo o autor defende que o desdobramento do debate sobre a agricultura é também um posicionamento político de Varrão. Deste modo, o elogio da agricultura, perante a uma visão pessimista desta atividade e em grande medida associado ao agrônomo Trémelio Scrofa, é também um elogio à Itália. Isso em razão desta região comportar todos os tipos de solos, o que impactaria de forma positiva a qualidade dos produtos desta região. Todavia, o autor alerta que o elogio da Itália era também uma exaltação dos cidadãos residentes na península itálica, sendo estes tipificados como os mais elevados, e consequentemente os mais adequados para o gerenciamento do Império.

Já o quarto e quinto capítulos, "The song of Faustlus: Pastures and Provinces in RR 2" e "Provincial Pastures: The Amoebean Refrain of Romulus in RR 2" são específicos sobre o segundo livro do tratado "varroniano", que tem como assunto 
principal a pecuária. Nestes capítulos o autor aborda de forma alegórico-metafórica que, enquanto a agricultura pode ser associada à Itália, a pecuária, por sua vez, estaria relacionada diretamente com a administração das províncias romanas. Para Grant Nelsestuen esta associação deriva do fato de que o segundo livro é resultado das conversas que Varrão alega ter tido com os pecuaristas da província grega de Épiro. Para tanto, os diferentes comportamentos dos animais remetiam as diferentes elites provinciais submetidas ao poder de Roma. Desta forma, Varrão e Trémelio Scrofa são apresentados como os pastores do Mediterrâneo, cuja finalidade seria domesticar os animais-elites em favor da dominação romana.

O sexto capítulo do livro, "Tending the Villa of Rome in RR 3" aborda o último diálogo do tratado de Varrão, dedicado ao debate sobre a gestão e função da villatica pastio. Ambientado na Villa Publica durante uma eleição para o cargo de edil, o autor propõe que o dialogo reflete sobre questões mais amplas sobre o governo da cidade de Roma. Divididos sobre a real função da casa de campo, os participantes debatem se sua finalidade deve obedecer apenas à obtenção de lucros, o deleite ou uma equação harmoniosa entres estas duas modalidades de casa de campo. Além do mais, os pássaros e os demais animais exóticos são associados aos cidadãos que, presos ao luxo da vida citadina, aludiam sobrea a progressiva perda de liberdade da aristocracia devido à crescente concentração de poder nas mãos dos generais romanos.

O último capítulo do livro, "Varro’s Imperial Estate and Its Intelecual Context" reflete sobre o contexto em que se insere o tratado de Varrão. O autor ressalta que o tratadista antecipa uma teoria do Império que somente se consolidaria com Augusto. Nesta ótica, o autor também ressalta que Varrão pode ser considerado um predecessor do desenvolvimento da teoria política moderna. Em suma, Grant Nelsestuen identifica que perpassava na mentalidade de Varrão uma distinção entre os espaços de ocupação geográfica decorrente do processo de expansão imperialista romana e uma correlação com as aristocracias situadas nestes diferentes territórios. Esta percepção se desdobraria em uma teoria política do Império em que a agricultura correspondia à Itália, a pecuária as províncias e a villatica pastio a cidade de Roma.

O conjunto do livro é resultado de um estudo meticuloso do tratado de Varrão e que se apresenta como uma alternativa inovadora para a historiografia que se deteve apenas aos aspectos econômicos, embora possa ser considerada bastante hipotética. Contudo, o autor não se dedica a um exame sobre a historiografia anterior, assim, ele acaba por projetar uma compreensão de que o debate político parece estar 
desassociado da esfera econômica ou de que de a promoção da atividade agropastoril, em detrimento de outras, não marcasse também uma posição política em um ambiente de intensa competição aristocrática. Não obstante a importante contribuição do autor, uma das lacunas do livro é a ausência da escravidão e demais grupos subalternos desta sociedade. Assim, a impressão é que estes grupos parecem não fazer parte ou não teriam importância na composição teórica do seu Império.

Resenha recebida em 01.06.2018, aprovada em 23.07.2018. 